\title{
Attitude towards entrepreneurship development courses of MOOCs
}

\author{
Md. Meraz Ahmed \\ School of Education, Bangladesh Open University, Gazipur, Bangladesh \\ Naveed Sultana \\ Secondary Teacher Education Department, Allama Iqbal Open University, \\ Islambad, Pakistan \\ Suhandoko Astri Dwi Jayanti \\ Faculty of Teacher Training and Education, Universitas Terbuka, \\ Tangerang Selatan, Indonesia \\ Yosi Mardoni
}

Faculty of Economics, Universitas Terbuka, Tangerang Selatan, Indonesia, and

Helmiatin Helmiatin

Universitas Terbuka, Tangerang Selatan, Indonesia

\begin{abstract}
Purpose - The purpose of the study was to explore the attitude of faculty members and students of two open universities - Bangladesh Open University (BOU) and Universitas Terbuka (UT) (Open University of Indonesia) towards entrepreneurship development courses of massive open online courses (MOOCs).

Design/methodology/approach - The mixed-method research design was employed for this study. A selfstructured survey questionnaire and focus group discussions (FGDs) were used to collect quantitative and qualitative data. A total of 66 faculty members and 149 tertiary level students of BOU and UT were selected as respondents. These respondents were selected using purposive sampling techniques. Data were analysed using quantitative and qualitative data analysis techniques.

Findings - The findings revealed that both universities' faculty members and students possessed a positive attitude towards entrepreneurship development courses of MOOCs (EDCM). However, this positive attitude of both groups was significantly different.

Originality/value - The policy recommendations could provide a strategic approach to developing various types of courses within the MOOC, which are attractive as a means of developing entrepreneurship in Bangladesh and Indonesia. It also aggressively promotes EDCM for the academic community in particular and society, in general, to elaborate on their entrepreneurial spirit. Nevertheless, before introducing MOOCs, an empirical study regarding MOOCs readiness is essential for both universities.
\end{abstract}

Keywords Attitude, Entrepreneurship development, MOOCs, Online learning

Paper type Research paper

\section{Introduction}

Unemployment is a global problem, and most developing countries are seriously suffering from this problem (Mallick and Biswas, 2020; Musa and Idris, 2020). Similarly, this problem is also

(C) Md. Meraz Ahmed, Naveed Sultana, Suhandoko Astri Dwi Jayanti, Yosi Mardoni and Helmiatin Helmiatin. Published in the Asian Association of Open Universities Journal. Published by Emerald Publishing Limited. This article is published under the Creative Commons Attribution (CC BY 4.0) licence. Anyone may reproduce, distribute, translate and create derivative works of this article (for both commercial and non-commercial purposes), subject to full attribution to the original publication and authors. The full terms of this licence may be seen at http://creativecommons.org/licences/by/4.0/legalcode

This study had been carried out with the support of the staff exchange fellowship programme of AAOU (Asian Association of Open Universities) and funded by Bangladesh Open University and Universitas Terbuka.

Attitude towards entrepreneurship development MOOCs

Received 19 October 2020 Revised 20 March 2021 29 March 2021

Accepted 30 March 2021 
AAOUJ 16,1

\section{0}

significantly alarming for Bangladesh and Indonesia (Mallick and Biswas, 2020; MarianaCristina, 2014). In 2019, according to the report of The World Bank, the unemployment rates of Bangladesh and Indonesia were 4.19 and 4.69\%, respectively (The World Bank, 2020).

In this scenario, Gamede and Uleanya (2018) and Mariana-Cristina (2014) argued that this global unemployment problem could be solved by developing entrepreneurship, a concept of establishing businesses that can solve social problems in a much more innovative way (Cárcamo-Solís et al., 2017). To do this, entrepreneurs have to be creative, a forecaster and risk-taker. Although there remains a myth that these virtues are inherent and cannot be taught, a good number of researchers argued that these entrepreneurship skills could be taught and also be learnt through entrepreneurship education (Al-Atabi and DeBoer, 2014; Cárcamo-Solís et al., 2017; Eesley and Lee, 2021). Arguing with this view, Welsh and Dragusin (2013) explored that massive open online courses (MOOCs) could play a crucial role in enhancing entrepreneurship development because entrepreneurship development courses of MOOCs (EDCM) provide entrepreneurship education which supports people to acquire the appropriate skills of entrepreneurship. In a study, Jones and Matlay (2011) claimed that MOOCs add convenience and economy in extending entrepreneurial education. Hence, the enriched entrepreneurial competencies are likely to accelerate the wander of novel venture formation, beget swift economic growth, elevate employment, generate value-added services and products, and improve living standards. After conducting an empirical study on university students, Al-Atabi and DeBoer (2014) also made a similar argument. Therefore, the Bangladesh Open University (BOU) of Bangladesh and the Universitas Terbuka (UT) of Indonesia could offer EDCM to increase the spirit of entrepreneurship, which hopes to have implications for both countries' unemployment rates.

Notwithstanding, the smooth operation and successful completion of any MOOCs are primarily dependent on the attitude of concerned parties (e.g. faculty members and students) (Aziz, 2018; Padilla Rodriguez et al., 2020; Zhou, 2016). This is also true for EDCM (Welsh and Dragusin, 2013). Therefore, before launching EDCM, it is logical to assess the faculty members' and the target students' attitude, capacity and motivation. These steps are also supportive for taking the right initiatives for effective implementation (Bakogianni et al., 2020; Gameel and Wilkins, 2019; James and Christian, 2016). Hence, before introducing EDCM by BOU and UT, it is needed to explore the attitude of faculty members and students of both universities towards EDCM. Considering these issues in mind, the researchers have formulated the following research questions for this study.

$R Q 1$. What is the attitude of faculty members of BOU and UT towards EDCM?

$R Q 2$. What is the attitude of tertiary level students of BOU and UT towards EDCM?

RQ3. Is there any difference between BOU and UT faculty members in terms of attitude towards EDCM?

$R Q 4$. Is there any difference between BOU and UT students in terms of attitude towards EDCM?

Thus, two hypotheses are postulated for RQ (III) and RQ (IV); these are:

H1. There is a significant difference between BOU and UT faculty members regarding attitude towards EDCM.

H2. There is a significant difference between BOU and UT students regarding attitude towards EDCM.

Both BOU and UT are prominent open and distance learning (ODL) universities, and the primary purpose of these universities is to produce skilled human resources 
(Akhter and Alam, 2016; Zuhairi, 2020). In line with this, both universities try to ensure quality education to the mass through the latest technologies (Hossain and Islam, 2015; Uddin and Hossain, 2019; Zuhairi, 2020). Thereby, both universities have taken initiatives to introduce online programmes and different MOOCs for their learners (Hossain and Islam, 2015; Uddin and Hossain, 2019; Zuhairi, 2020). This study will provide the necessary information regarding faculty members and students' attitude towards EDCM, which could be of productive use in introducing EDCM. This study has explored the beneficial baseline information of faculty members and students regarding MOOCs, which could help to introduce EDCM convenient for the students.

\section{Review of the literature}

The term entrepreneurship has been conceptualised in several ways. According to Al-Atabi and DeBoer (2014), entrepreneurship involves individuals' positive attitude towards identifying innovative business opportunities and developing new businesses accordingly. Despite this, Toma et al. (2014) argued that entrepreneurship is not only to start new businesses but also to enhance existing businesses' productivity by employing innovative approaches. Therefore, it involves creative activities which produce new employment opportunities that ultimately accelerate economic growth.

This entrepreneurship can be developed, and the process by which concerned entities develop entrepreneurs is called entrepreneurship development. Many researchers have given several conceptional frameworks for it. For example, Cárcamo-Solís et al. (2017) explained that it could be developed at the elementary level by playing entrepreneurial games among kids. Similarly, at the secondary level, Sithole and Lumadi (2012) explored that mini enterprises directed by the students enhanced students' entrepreneurial skills. In terms of the tertiary level, Belz and Binder (2017) presented a six-phase convergent process framework that would make sustainable entrepreneurship. Saeed et al. (2015) explored that university support in terms of education, concept development and business development can develop students' entrepreneurial intentions and motivate them to start a new business. Besides, a number of researchers confirmed that entrepreneurship education and training programmes of universities are also the ways of developing entrepreneurship (Iglesias-Sánchez et al., 2016; Nieminen and Hytti, 2016).

The main aim of entrepreneurship development programmes is to reduce the unemployment rate. In a study, after analysing data from the Global Entrepreneurship Monitor reports of South Africa (period 2000/01 to 2016/17), Musara et al. (2020) revealed that entrepreneurship development programmes significantly reduce the unemployment rate of South Africa. They argued that entrepreneurship education enhances entrepreneurial activities, which ultimately increase self-employment and decrease the unemployment rate. Thereby, they recommended that more entrepreneurship education is needed for eradicating the unemployment problem. A similar argument was also made by Cueto et al. (2015) in the context of Spain. On the other hand, higher unemployment rates accelerate entrepreneurship activities; in turn, higher entrepreneurship activities decrease the unemployment rate (Apergis and Payne, 2016; Dvouletý, 2017). Hence, by reducing the unemployment rate, entrepreneurship development programmes essentially contribute to poverty alleviation and economic development (Mahadea and Kaseeram, 2018; Toma et al., 2014). To capture these overwhelming benefits, universities worldwide offer diverse entrepreneurship development courses (Eesley and Lee, 2021; Iglesias-Sánchez et al., 2016).

The nature of entrepreneurship development courses is different from other courses (Jones and English, 2004). For illustration, these courses pursue to endow the participants with essential competencies and skills, which may transmute ideas into action (Álvarez-Castañón and Arroyo, 2021). Therefore, these are activity-oriented and difficult to teach through the traditional classroom-based teaching-learning system (Al-Atabi and DeBoer, 2014; Vorbach
Attitude towards entrepreneurship development MOOCs 
AAOUJ 16,1 et al., 2019). Additionally, due to the business world's dynamic nature, people continuously have to acquire entrepreneurial knowledge and skills through these courses (Jones and English, 2004; Vorbach et al., 2019). Furthermore, these courses' curriculum and teachinglearning process are influenced by the latest educational technologies that have brought a paradigm transformation for these courses (Kazakeviciute et al., 2016; Vorbach et al., 2019). According to Al-Atabi and DeBoer (2014), online or web-based entrepreneurship education may substantially impact students' entrepreneurial attitudes and skills. Moreover, because of the several barriers like time, expense and place, it becomes difficult for people to enrol in these courses through the traditional face-to-face system (Kazakeviciute et al., 2016).

In this aspect, MOOCs could be the feasible approach to offer continuous entrepreneurship education to the mass because MOOCs are flexible, open access, low cost, mass enrolment and web-based courses (Aziz, 2018; Padilla Rodriguez et al., 2020; Soylev, 2017). Additionally, these are customised and short-term skills development-related educational courses which present the opportunity to learn from anywhere only with Internet connectivity (Conole, 2020; Pujar and Tadasad, 2016). Hence, MOOCs learners can learn in their way and complete a course without any cost or at a meagre cost (Pujar and Tadasad, 2016). In these ways, they can increase their knowledge and skills in their free time without hindering their regular work and study. Besides, certificate achievement is one of the motivational factors for students (Deng et al., 2019). Due to these distinctive advantages, tertiary students have a positive attitude towards MOOCs (Shapiro et al., 2017). Furthermore, Mondal et al. (2015) argued that MOOCs bring tremendous benefits regarding time and cost, routing geographical boundaries, amputating entry barriers and advocating entrepreneurial education to a more significant extent to students and professionals. They further explored that a revolutionary change may be brought about in the mindset of the youth, inspiring them to stimulate entrepreneurial ventures through MOOCs.

To that end, at present, a significant number of universities are conducting entrepreneurship development-related courses via MOOCs. For example, Taylor's University offers an entrepreneurship development course called "Global Entrepreneurship" through the OpenLearning.com platform. The link to this course is https://www.openlearning.com/courses/ Entrepreneurship (Al-Atabi and DeBoer, 2014). Vorbach et al. (2019) and Welsh and Dragusin (2013) explored three specific reasons for conducting these courses via MOOCs. Firstly, people have an interest in EDCM. Secondly, many people want to learn entrepreneurial skills free of cost. Thirdly, these courses provide many new business ideas, especially for those who come from developing countries such as Indonesia and Bangladesh. In terms of benefits, recently, Guerrero et al. (2021) and Solórzano-García et al. (2020) explored that EDCM can improve learners' skills in running their current business as well as enhance their competence to develop a new business.

On the other hand, several studies documented certain factors that significantly influence the success of any MOOCs, including EDCM. For instance, Shapiro et al. (2017) mentioned that available time, MOOCs readiness and subject and technological knowledge are the main factors for enrolling in any MOOCs. Regarding course management and completion, the attitude of the faculty members and the students is a major influencing factor for the smooth operation and successful completion of MOOCs (Bakogianni et al., 2020; Subramaniam et al., 2019). Similarly, Zhou (2016) argued that students' attitude towards MOOCs significantly impacts using MOOCs. Recently, Ricart et al. (2020) explored that MOOC-takers' engagement, academic performance and the completion-dropout rate are significantly influenced by their attitude.

Therefore, it is logical to assess the attitude of faculty members and students towards MOOCs before lunching any kinds of MOOCs including EDCM. A neutral or negative attitude may create challenges for institutions for the sound management of MOOCs (Deng et al., 2019). There are several studies regarding attitudes and MOOCs readiness of faculty 
members and students of face-to-face educational institutions (Bakogianni et al., 2020; Deng et al., 2019). In addition, there are some studies on this topic from the open university perspective. Moreover, there are a few studies on this topic from either the BOU or UT perspective. However, a comparative study between these two universities on this topic is scarce. Hence, this study will try to fill up this gap.

\section{Methodology}

The mixed-method research design was employed to conduct this study. Thus, this study focuses on both types of data, i.e. quantitative and qualitative data. To acquire more expressive and in-depth data from the key participants (i.e. faculty members and tertiary level students of BOU and UT), two self-structured survey questionnaires (one is for faculty members and another is for students) were used to collect quantitative data. Besides, four focus group discussions (FGDs) and eight personal interviews for both types of participants, equal for each type, were also conducted to gather qualitative data. The open-ended part of the questionnaires also served as a source of qualitative data. The mixed method allowed the researchers to address the research questions comprehensively (Caruth, 2013; Creswell, 2012). For instance, quantitative data analysis explored the attitude of participants towards $\mathrm{EDCM}$ in a visual manner. In contrast, qualitative data analysis allowed the researchers to explore the participants' attitudes and feelings and beliefs about EDCM in a much more explanatory way (Creswell, 2012).

\subsection{Population, samples and sampling procedure}

Faculty members and tertiary level students of BOU and UT were the population of this study. Among the population, active faculty members and tertiary level students of BOU and UT had constituted the samples of this study. They were selected through a purposive sampling procedure (Creswell, 2012). To achieve a representative sample, 38 faculty members of BOU and 28 faculty members of UT and 76 and 73 tertiary level students of BOU and UT, respectively, were selected as a sample from the whole population.

\subsection{Method of data analysis}

A mixed-method approach was used to analyse the data because it focused on both analytical techniques, that is, qualitative and quantitative. After collecting all data, participants were allocated a pseudonym. The researchers primarily focused on quantitative data analysis as the attitude towards EDCM was explored statistically. The researchers also interpreted the data given by the participants specific to each question. SPSS was used to perform descriptive and multi-level quantitative data analysis. Besides, for the qualitative part, "frequencies and occurrences of responses" (Cohen et al., 2007) were calculated, and the participants' opinions were presented in narrative form. Thus, mixed-method research design allowed an in-depth interpretation of data and triangulation of study outcomes produced from two research designs.

\section{Findings}

To explore the attitude towards EDCM, both types of data were collected, analysed and interpreted. Main findings derived from the analysis are presented and interpreted in the following section.

\subsection{Attitude of faculty members of Bangladesh Open University and UT towards EDCM}

After analysing quantitative and qualitative data collected from both sources, that is, primary and secondary, it was found that BOU had already developed its own Learning 
AAOUJ

16,1

\section{4}

Table 1.

Opinion of faculty members towards EDCM
Management System (LMS) for delivering online programmes and MOOCs. In contrast, UT already had online programmes as well as MOOCs.

Table 1 shows that only $44 \%$ of the faculty members of BOU agreed with the statement that the learning culture of BOU was suitable for introducing EDCM. In comparison, $79 \%$ of the faculty members of UT agreed with this statement. Besides, 70 and $86 \%$ of BOU and UT faculty members agreed that MOOCs are the appropriate way to teach EDCM. Of the faculty members of BOU, $53 \%$ thought that BOU was ready to offer EDCM; in contrast, $82 \%$ of the UT faculty members believed that UT was prepared for launching EDCM.

In FGD sessions, faculty members of BOU and UT in the sample were also asked why they think that the learning culture of BOU/UT was suitable for introducing EDCM. Faculty members' voices derived from FGDs for this purpose are given below, which reflected the above factors such as, "I think that UT should introduce entrepreneurship courses through MOOCs because one of the visions of UT is to create entrepreneur. Besides, UT can build a worldwide image by offering entrepreneur courses through MOOCs. Although MOOCs courses are free, UT can earn revenue by applying small fees for MOOCs certificate". (faculty members of UT)

I think that by offering EDCM, UT can go international, which is one of the visions of UT. In addition, UT can offer EDCM for community development purposes. However, The Government can make entrepreneurs by its one program, but it will cover a minimal area of Indonesia, but if we (UT) offer EDCM, it will work for all over the country even abroad. (faculty members of UT)

Conversely, most of the faculty members of BOU mentioned that the learning culture of BOU is not suitable for EDCM because people were not aware of MOOCs and most of the learners of Bangladesh wanted to learn through the face-to-face system. Besides, technological facilities were not available in rural areas. Moreover, learners need more time to adopt technological advancement.

Again, why are MOOCs appropriate for teaching entrepreneurship? This question was also to asked the faculty members of both universities who participated in FGD sessions. Analysing their opinions, several common factors were identified as the reasons for their preference. For example, most of the faculty members argued that anyone could enrol in MOOCs, and it is flexible, affordable and convenient in terms of time and location. One faculty member's voice derived from FGDs was, "I think MOOCs courses are free which ensure a large number of enrollments." (faculty members of BOU). Still, some faculty members wanted to teach entrepreneurship courses through a traditional classroom setting because they thought learners were habituated to learn through a traditional classroom setting, and teaching entrepreneurial skills through MOOCs would be very difficult.

In terms of preparedness, both universities' faculty members argued that both universities could offer EDCM with existing infrastructure. By analysing FGD responses, it was found that UT had a platform, infrastructural support, skilled faculty members and technical workforce and already had experience of running MOOCs. These factors may help UT to

\begin{tabular}{lcccc}
\hline & \multicolumn{2}{c}{ BOU } & \multicolumn{2}{c}{ UT } \\
Items & $\begin{array}{c}\text { Agree } \\
(\%)\end{array}$ & $\begin{array}{c}\text { Disagree } \\
(\%)\end{array}$ & $\begin{array}{c}\text { Agree } \\
(\%)\end{array}$ & $\begin{array}{c}\text { Disagree } \\
(\%)\end{array}$ \\
\hline $\begin{array}{l}\text { (1) Learning culture is appropriate for introducing } \\
\text { EDCM in BOU/UT }\end{array}$ & $44 \%$ & $56 \%$ & $79 \%$ & $21 \%$ \\
$\begin{array}{l}\text { (2) MOOCs are appropriate for teaching } \\
\text { entrepreneurship courses }\end{array}$ & $70 \%$ & $30 \%$ & $86 \%$ & $14 \%$ \\
$\begin{array}{l}\text { (3) BOU/UT is prepared to introduce EDCM } \\
\text { Source(s): Primary data collected from field work, October } 2018\end{array}$ & $53 \%$ & $82 \%$ & $18 \%$ \\
\hline
\end{tabular}


offer EDCM. Faculty members also mentioned several challenges like lack of skilled faculty members and time.

To explore faculty members' attitude quantitively, 15 items were used on an ordinal scale from 1 (strongly agree) to 5 (strongly disagree). The Cronbach's alpha value for these 15 items was 0.959, which indicated an excellent internal consistency score (Blunch, 2008). The standard deviation (SD) scores varied from 0.52 to 1.03 , indicating a narrow spread of items' values around the mean score. Table 2 shows the attitude of faculty members. Faculty members of both universities possessed a positive attitude towards EDCM because each item's mean score exceeded the neutral value except one item - item number 15 for BOU which was below the neutral value. Besides, UT faculty members' overall mean value was 3.95 , which was comparatively higher than the mean value of BOU, that is, 3.59 .

\subsection{Attitude of tertiary level students of Bangladesh Open University and Universitas}

Terbuka towards entrepreneurship development courses of massive open online courses

An ordinal scale explored the attitude of tertiary level students of BOU and UT from 1 (strongly agree) to 5 (strongly disagree) containing 18 items. The Cronbach's alpha value for these 18 items is 0.850 indicating an acceptable internal consistency value (Blunch, 2008). The standard deviation (SD) scores varied from 0.53 to 1.31 showing a narrow spread of the values of items around the mean score. Table 3 illustrates the attitude of tertiary level students of BOU and UT. The mean value of all items exceeds the neutral value that indicates students possessed a positive attitude towards EDCM. However, BOU students kept a higher positive attitude than the UT students because the overall mean value of the students of BOU is 4.35 , higher than the mean value of the students of UT, that is, 3.84 .

\subsection{Difference between the faculty members of Bangladesh Open University and Universitas Terbuka in terms of attitude towards entrepreneurship development courses of massive open online courses}

One sample $t$-test was used to explore the difference between the two groups of faculty members regarding the attitude towards EDCM. More specifically, overall mean values of the

\begin{tabular}{|c|c|c|c|c|c|}
\hline \multirow{2}{*}{ Items } & & \multicolumn{2}{|c|}{$\mathrm{BOU}$} & \multicolumn{2}{|c|}{ UT } \\
\hline & & Mean & $\mathrm{SD}$ & Mean & $\mathrm{SD}$ \\
\hline$(1)$ & MOOCs are good way to acquire new knowledge of entrepreneurship & 3.84 & 0.72 & 4.18 & 0.9 \\
\hline$(2)$ & $\begin{array}{l}\text { Repeatability of MOOCs is helpful for understanding the content of } \\
\text { entrepreneurship development courses deeply }\end{array}$ & 3.89 & 0.69 & 4.21 & \\
\hline$(3)$ & EDCM have convenience in terms of own time and location & 3.68 & 0.62 & 4.00 & 0.86 \\
\hline (4) & EDCM give new business ideas & 4.03 & 0.60 & 4.07 & 0.60 \\
\hline (5) & EDCM inspire students to become an entrepreneur & 3.84 & 0.59 & 4.00 & 0.8 \\
\hline$(6)$ & EDCM help students to acquire business skills & 3.67 & 0.72 & 4.07 & 0.77 \\
\hline (7) & EDCM help students to start own business & 3.55 & 0.76 & 3.89 & 0.8 \\
\hline$(8)$ & EDCM help an entrepreneur for lifelong learning & 3.68 & 0.70 & 4.11 & 0.92 \\
\hline (9) & EDCM will create entrepreneurs & 3.68 & 0.52 & 3.93 & 0.8 \\
\hline$(10)$ & By using EDCM BOU and UT can create entrepreneurs at low cost & 3.61 & 0.64 & 4.07 & 0.90 \\
\hline$(11)$ & By using EDCM BOU and UT can create entrepreneurs very shortly & 3.21 & 0.74 & 3.82 & 1.0 \\
\hline$(12)$ & $\begin{array}{l}\text { By using EDCM BOU and UT can create a large number of } \\
\text { entrepreneurs }\end{array}$ & 3.28 & 0.88 & 3.54 & 0.9 \\
\hline$(13)$ & $\begin{array}{l}\text { EDCM will gain rapid popularity among the tertiary level students of } \\
\text { BOU and UT }\end{array}$ & 3.39 & 0.68 & 3.75 & 0.8 \\
\hline$(14)$ & By offering EDCM BOU and UT can solve unemployed problem & 3.24 & 0.82 & 3.89 & 1.0 \\
\hline$(15)$ & $\begin{array}{l}\text { Tertiary level students of BOU and UT have enough technical support } \\
\text { for receiving EDCM }\end{array}$ & 2.79 & 1.02 & 3.71 & 0.9 \\
\hline Over & rall attitude of faculty members towards EDCM & 3.59 & 0.39 & 3.95 & 0.7 \\
\hline
\end{tabular}

Attitude towards entrepreneurship development MOOCs

\section{5}


AAOUJ 16,1

Table 3.

Attitude of tertiary level students of BOU and UT towards EDCM
Items

BOU

UT

Mean SD Mean SD

(1) I want to be an entrepreneur

(2) I want to start my own business rather than doing job

(3) For entrepreneurship development courses I prefer to learn through a MOOCs rather than the traditional classroom teaching

(4) I am ready to admit any course related to entrepreneurship development offered by MOOCs

(5) I think that EDCM have convenience in terms of my own time and location

(6) I think that I will get new business ideas after completing EDCM

(7) I think that EDCM help me to acquire business knowledge and skills

(8) I think that we will be benefited if BOU and UT introduce EDCM

(9) I have regular access to a computer with an Internet connection

(10) I have the basic skills for using the internet (e.g. using search engines, Social Media)

(11) I have experience using software such as Microsoft Office (e.g. Word, PowerPoint, and Excel)

(12) I think that I would be able to communicate effectively with others using online technologies (e.g. chat)

(13) I think that I would be comfortable using a computer several times a week to participate in a course

(14) I think that I would be able to understand course related information when it's presented in video formats

(15) I am able to spend approximately $9 \mathrm{~h}$ a week on lessons/activities/ homework/readings for every 3-credit course in which I am enrolled

4.29

0.66

$\begin{array}{llll}4.39 & 0.81 & 4.12 & 0.73\end{array}$

$\begin{array}{llll}4.18 & 0.80 & 3.03 & 0.89\end{array}$

$\begin{array}{llll}4.32 & 0.87 & 3.57 & 0.65\end{array}$

$\begin{array}{llll}4.27 & 0.81 & 3.61 & 0.81\end{array}$

$\begin{array}{llll}4.35 & 0.76 & 3.81 & 0.60\end{array}$

$\begin{array}{llll}4.42 & 0.77 & 4.01 & 0.54\end{array}$

$\begin{array}{llll}4.56 & 0.70 & 3.96 & 0.60\end{array}$

$\begin{array}{llll}4.55 & 0.93 & 4.17 & 0.61\end{array}$

$\begin{array}{llll}4.71 & 0.63 & 4.26 & 0.53\end{array}$

$\begin{array}{llll}4.53 & 0.84 & 4.29 & 0.60\end{array}$

$\begin{array}{llll}4.61 & 0.61 & 4.00 & 0.61\end{array}$

$\begin{array}{llll}4.40 & 0.81 & 3.76 & 0.62\end{array}$

$\begin{array}{llll}4.55 & 0.72 \quad 4.10 \quad 0.59\end{array}$

$\begin{array}{llll}4.08 & 0.84 & 3.33 & 0.61\end{array}$

$\begin{array}{llll}3.22 & 1.31 & 3.12 & 0.83\end{array}$

(16) I have experience using a Learning Management System (iFolio, SPIN, Moodle, etc.)

(17) I can learn from a various instructional format (e.g. text, video, podcast, online discussions, and video conferencing)

(18) I think that EDCM will gain rapid popularity among the tertiary level students of BOU and UT

Overall attitude towards EDCM of students

Source(s): Primary data collected from field work, October 2018

$\begin{array}{llll}4.29 & 0.88 & 3.94 & 0.63\end{array}$

$\begin{array}{llll}4.38 & 0.88 & 3.92 & 0.55\end{array}$

$\begin{array}{llll}4.35 & 0.39 & 3.84 & 0.27\end{array}$

faculty members of UT were considered; the comparison values and corresponding overall mean values of BOU faculty members were the variables under consideration. Table 4 shows a significant difference between the two groups of the faculty members in terms of the attitude towards EDCM as $p<0.05$. Therefore, the null hypothesis is rejected for the H1.

\subsection{Difference between the tertiary level students of Bangladesh Open University and Universitas Terbuka in terms of attitude towards entrepreneurship development courses of massive open online courses}

As like the faculty members, the one-sample $t$-test was also used to explore the difference between the two groups of students regarding their attitude towards EDCM. Here, the overall

Table 4.

Difference between the faculty members of BOU and UT in terms of attitude towards EDCM

\begin{tabular}{|c|c|c|c|c|c|c|c|c|}
\hline & \multirow{2}{*}{$\begin{array}{l}\text { Mean } \\
\text { (BOU) }\end{array}$} & \multirow{2}{*}{$\begin{array}{l}\text { Test } \\
\text { value } \\
\text { (UT) }\end{array}$} & \multirow[b]{2}{*}{$t$} & \multirow[b]{2}{*}{$\mathrm{df}$} & \multirow{2}{*}{$\begin{array}{c}\text { Mean } \\
\text { difference }\end{array}$} & \multirow{2}{*}{$\begin{array}{l}\text { Sig. } \\
\text { (2-tailed) }\end{array}$} & \multicolumn{2}{|c|}{$\begin{array}{l}95 \% \text { confidence } \\
\text { interval of the } \\
\text { difference }\end{array}$} \\
\hline & & & & & & & Lower & Upper \\
\hline $\begin{array}{l}\text { Faculty members' } \\
\text { attitude towards } \\
\text { EDCM }\end{array}$ & 3.59 & 3.95 & -6.217 & 37 & -0.39110 & 0.000 & -0.5186 & -0.2636 \\
\hline
\end{tabular}


mean values of the UT students were considered the comparison values and corresponding overall mean values of the students of BOU were the variables under consideration. Table 5 shows a significant difference between the two groups of the students in terms of their attitude towards EDCM as $p<0.05$. Therefore, null hypotheses are also rejected for the H2.

\section{Discussions}

This study intended to explore the attitude regarding the EDCM of faculty members and students of both universities. The findings related to research question 1 revealed that most of the faculty members of BOU disagreed with the statement that the learning culture of BOU students was suitable for introducing EDCM. This finding was expected because Mou (2016) explored several challenges of online learning in Bangladesh, such as underdeveloped Information and Communication Technology (ICT) infrastructure, lack of skilled teachers, inadequate funds, traditional beliefs and attitude of teachers, lack of time and language barriers. However, most of the BOU faculty members agreed that MOOCs were one of the best ways to teach entrepreneurship; similar finding were also mentioned by Al-Atabi and DeBoer (2014) and Welsh and Dragusin (2013). BOU had sufficient infrastructure for offering EDCM, agreed by $53 \%$ of BOU faculty members (Akhter and Alam, 2016). Besides, faculty members of BOU possessed a positive attitude towards EDCM. This had occurred because BOU shifted their entire operation from traditional ODL to digital ODL (Hossain and Islam, 2015; Islam and Ferdowsi, 2014; Uddin and Hossain, 2019).

On the other hand, most of the UT faculty members agreed with the three statements and possessed a more positive attitude regarding EDCM than the faculty members of BOU. These findings are well supported by the work of Zuhairi (2020). According to Zuhairi (2020), UT had already taken several initiatives for transforming itself into a modern cyber ODL university. For instance, it introduced MOOCs, digital library, fully online programmes and Open Educational Resources (OER) for the learners. Hence, these initiatives made the faculty members more positive towards EDCM (see Table 4).

The findings related to research question 2 revealed that tertiary level students of BOU also possessed a positive attitude towards EDCM and interestingly their positive mean values were higher than the positive mean of the students of UT although they had no MOOCs that time. These findings were well supported by several studies (Hansson et al., 2018; Khan, 2014; Mou, 2016) and the government reports of Bangladesh because the Government of Bangladesh had taken numerous steps for digitalising its education systems like an adaptation of National ICT Policy-2009, National Educational Policy-2010 and the master plan of integrating ICT in education (Ministry of Education, 2016). Besides, Bangladesh's government had also taken various projects like access to information (a2i), teaching quality improvement projects. Similarly, under the supervision of a2i, 38,331 digital classrooms were introduced countrywide, and a teachers' portal named teachers.gov.bd and an e-learning platform called "Muktopaath" were also developed (Hansson et al., 2018). Thereby, in line with this digitalisation, BOU had already developed its own LMS for

\begin{tabular}{|c|c|c|c|c|c|c|c|c|c|}
\hline & \multirow{2}{*}{$\begin{array}{l}\text { Mean } \\
(\mathrm{BOU})\end{array}$} & \multirow{2}{*}{$\begin{array}{l}\text { Test } \\
\text { value } \\
\text { (UT) } \\
\end{array}$} & \multirow[b]{2}{*}{$t$} & \multirow{2}{*}{ df } & \multirow{2}{*}{$\begin{array}{c}\text { Mean } \\
\text { difference }\end{array}$} & \multirow{2}{*}{$\begin{array}{c}\text { Sig. } \\
\text { (2-tailed) }\end{array}$} & \multicolumn{2}{|c|}{$\begin{array}{l}95 \% \text { confidence } \\
\text { interval of the } \\
\text { difference }\end{array}$} & \multirow{3}{*}{$\begin{array}{r}\text { Table } 5 . \\
\text { Difference between the } \\
\text { tertiary level students } \\
\text { of BOU and UT in } \\
\text { terms of attitude } \\
\text { towards EDCM }\end{array}$} \\
\hline & & & & & & & Lower & Upper & \\
\hline $\begin{array}{l}\text { Tertiary level } \\
\text { students' attitude } \\
\text { towards EDCM }\end{array}$ & 4.35 & 3.84 & 11.163 & 75 & 0.50795 & 0.000 & 0.4183 & 0.5986 & \\
\hline
\end{tabular}

Attitude towards entrepreneurship development MOOCs

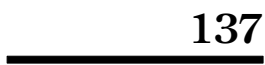


AAOUJ 16,1

\section{8}

introducing online courses and MOOCs (Uddin and Hossain, 2019). Therefore, due to these numerous steps, the learning culture of the tertiary students of BOU was changing which support these findings.

On the other side, the tertiary level students of UT also possessed a positive attitude towards EDCM because UT had already introduced MOOCs in different educational areas. UT provided online tutorial, online learning platform, online access to the digital library, digital learning materials, virtual lab, online course enrolment, online academic support, access to OERs, iTV, iRadio and online examination to their students (Zuhairi, 2020). Therefore, due to these numerous facilities students became positive towards EDCM.

The findings related to research questions 3 and 4 rejected the null hypotheses in both cases and explored a significant difference in terms of attitude towards EDCM between both groups, that is, faculty members and students of BOU and UT. These findings were expected because both universities had different learning culture, infrastructure, educational programmes, vision, mission, objectives and also different strategic approaches (Akhter and Alam, 2016; Hossain and Islam, 2015; Uddin and Hossain, 2019; Zuhairi, 2020).

\section{Conclusion}

The findings of this study are helpful for policymakers for taking the necessary steps to introduce and maintain EDCM. These findings will have implications for policymakers as these will provide relevant information regarding the problems, prospects and implementation of EDCM in BOU and UT. Besides, these findings are also expected to give an insight into the importance of MOOCs for entrepreneurship development of other developing countries and will indicate strategies for improvement. This study concludes that both universities should introduce EDCM, but before introducing EDCM, both universities should take initiatives to develop the faculty members and infrastructure. For the smooth management and further development of EDCM, both universities should have a strategic plan and conduct empirical studies regarding MOOCs readiness of faculty members and students.

\section{References}

Akhter, N. and Alam, S. (2016), "Status of teachers education and training at secondary level of general education in Bangladesh", American Journal of Educational Research, Vol. 4 No. 12, pp. 907-913.

Al-Atabi, M. and DeBoer, J. (2014), "Teaching entrepreneurship using massive open online course (MOOC)", Technovation, Vol. 34 No. 4, pp. 261-264, available at: https://doi-org.ezproxy. nottingham.edu.my/10.1016/j.technovation.2014.01.006.

Álvarez-Castañón, L.D.C. and Arroyo, P. (2021), in Jones, P., Apostolopoulos, N., Kakouris, A., Moon, C., Ratten, V. and Walmsley, A. (Eds), "Effect of entrepreneurship training on students' capability of agency and entrepreneurship intention", Universities and Entrepreneurship: Meeting the Educational and Social Challenges (Contemporary Issues in Entrepreneurship Research, Emerald Publishing, Vol. 11, pp. 81-95, doi: 10.1108/S2040-724620210000011006.

Apergis, N. and Payne, J.E. (2016), "An empirical note on entrepreneurship and unemployment: further evidence from US States”, Journal of Entrepreneurship and Public Policy, Vol. 5 No. 1, pp. 73-81, doi: 10.1108/JEPP-10-2015-0029.

Aziz, A. (2018), "Evaluating the design standard of UiTM massive open online courses", International Journal of Education and Literacy Studies, Vol. 6 No. 4, pp. 138-151.

Bakogianni, E., Tsitouridou, M. and Kyridis, A. (2020), "MOOCs in teachers' professional development: examining teacher readiness", Academia - Boletín de la Real Academia de Bellas Artes de San Fernando, Vol. 18, pp. 9-40.

Belz, F.M. and Binder, J.K. (2017), "Sustainable entrepreneurship: a convergent process model", Business Strategy and the Environment, Vol. 26 No. 1, pp. 1-17, doi: 10.1002/bse.1887. 
Blunch, N. (2008), Introduction to Structural Equation Modelling Using SPSS and AMOS, Sage Publications, London.

Caruth, G.D. (2013), "Demystifying mixed methods research design: a review of the literature", Online Submission, Vol. 3 No. 2, pp. 112-122.

Cohen, L., Manion, L. and Morrison, K. (2007), Research Methods in Education, 5th ed., Routledge, Falmer, London.

Conole, G. (2020), "Book review: MOOCs and open education in the global south: challenges, successes, and opportunities", Asian Journal of Distance Education, Vol. 15 No. 1, pp. 307-308.

Creswell, J.W. (2012), Educational Research: Planning, Conducting and Evaluating Quantitative and Qualitative Research, 4th ed., Pearson Education, Boston, MA.

Cueto, B., Mayor, M. and Suárez, P. (2015), "Entrepreneurship and unemployment in Spain: a regional analysis”, Applied Economics Letters, Vol. 22 No. 15, pp. 1230-1235, doi: 10.1080/13504851.2015. 1021450.

Cárcamo-Solís, M.D.L., Arroyo-López, M.D.P., Alvarez-Castañón, L.D.C. and García-López, E. (2017), "Developing entrepreneurship in primary schools. The Mexican experience of My first enterprise: entrepreneurship by playing”, Teaching and Teacher Education, Vol. 64, pp. 291-304, doi: 10.1016/j.tate.2017.02.013.

Deng, R., Benckendorff, P. and Gannaway, D. (2019), "Progress and new directions for teaching and learning in MOOCs", Computers and Education, Vol. 129, pp. 48-60.

Dvouletý, O. (2017), "What is the relationship between entrepreneurship and unemployment in Visegrad countries?”, Central European Business Review, Vol. 6 No. 2, pp. 42-53, doi: 10.18267/j. cebr.179.

Eesley, C.E. and Lee, Y.S. (2021), "Do university entrepreneurship programs promote entrepreneurship?”, Strategic Management Journal, Vol. 42 No. 4, pp. 833-861, doi: 10.1002/ smj.3246.

Gamede, B.T. and Uleanya, C. (2018), "Entrepreneurship: solution to unemployment and development in rural communities”, Journal of Entrepreneurship Education, Vol. 21, pp. 1-12.

Gameel, B.G. and Wilkins, K.G. (2019), "When it comes to MOOCs, where you are from makes a difference”, Computers and Education, Vol. 136, pp. 49-60, doi: 10.1016/j.compedu.2019.02.014.

Guerrero, M., Heaton, S. and Urbano, D. (2021), "Building universities' intrapreneurial capabilities in the digital era: the role and impacts of Massive Open Online Courses (MOOCs)", Technovation, Vol. 99, p. 102139, doi: 10.1016/j.technovation.2020.102139.

Hansson, H., Sultana, S., Sarwar, A., Ahmed, F., Uddin, R., Saha, P., Islam, G. and Islam, M. (2018), "The teachers' portal as a tool for teachers' professional development in Bangladesh: facilitating nationwide networking and digital multimedia content for 40,000 schools", International Journal of Education and Development using Information and Communication Technology, Vol. 14 No. 3, pp. 113-130.

Hossain, M.F. and Islam, M.A. (2015), "Bangladesh Open University educating people through distance mode”, International Journal of Educational Studies, Vol. 2 No. 1, pp. 37-43.

Iglesias-Sánchez, P.P., Jambrino-Maldonado, C., Velasco, A.P. and Kokash, H. (2016), "Impact of entrepreneurship programmes on university students”, Education + Training, Vol. 58 No. 2, pp. 209-228, doi: 10.1108/ET-01-2015-0004.

Islam, A. and Ferdowsi, S. (2014), "Meeting the needs of distance learners of M. Ed program: Bangladesh Open University perspective", The Turkish Online Journal of Distance Education, Vol. 15 No. 2, pp. 175-193.

James, P.K. and Christian, I.E. (2016), "Learners Readiness for xMOOCs: inequity in Nigeria", European Journal of Computer Science and Information Technology, Vol. 4 No. 3, pp. 16-46.

Jones, C. and English, J. (2004), “A contemporary approach to entrepreneurship education”, Education Training, Vol. 46 Nos 8/9, pp. 416-423.
Attitude towards entrepreneurship development MOOCs 
AAOUJ 16,1

Jones, C. and Matlay, H. (2011), "Understanding the heterogeneity of entrepreneurship education: going beyond gartner", Education + Training, Vol. 53 Nos 8/9, pp. 692-703, doi: 10.1108/ 00400911111185026.

Kazakeviciute, A., Urbone, R. and Petraite, M. (2016), "Curriculum development for technology-based entrepreneurship education: a cross-disciplinary and cross-cultural approach”, Industry and Higher Education, Vol. 30 No. 3, pp. 202-214.

Khan, S. (2014), "A model for integrating ICT into teacher training programs in Bangladesh based on TPCK", International Journal of Education and Development using Information and Communication Technology, Vol. 10 No. 3, pp. 21-31.

Mahadea, D. and Kaseeram, I. (2018), "The relationship between unemployment, entrepreneurship, rising income in South Africa: an exploratory study", African Journal of Business and Economic Research, Vol. 13 No. 2, pp. 203-226, doi: 10.31920/1750-4562/2018/v13n2a10.

Mallick, U.K. and Biswas, M.H.A. (2020), "Mathematical approach with optimal control: reduction of unemployment problem in Bangladesh", Journal of Applied Nonlinear Dynamics, Vol. 9 No. 2, pp. 231-246.

Mariana-Cristina, G. (2014), "Entrepreneurship, a solution to improve youth employment in the European Union”, Strategii Managerial, Vol. 4, pp. 580-588.

Ministry of Education (2016), "Master plan for information and communication technology in education (2012-2021)", available at: https://moedu.gov.bd/site/page/2859c582-aaf8-40bb-909c57b409ead7d6/ (accessed 29 September 2020).

Mondal, M.K., Kumar, A. and Bose, B.P. (2015), "October. Entrepreneurship education through MOOCs for accelerated economic growth”, 2015 IEEE $3 r d$ International Conference on MOOCs, Innovation and Technology in Education (MITE), Amritsar, India, 1-2 October 2015, pp. 407-411, doi: 10.1109/MITE.2015.7375354.

Mou, S. (2016), "Possibilities and challenges of ICT integration in the Bangladesh education system", Educational Technology, Vol. 26 No. 2, pp. 50-53.

Musa, S.F.P.D. and Idris, D.S.R.P.H. (2020), "Addressing issues of unemployment in Brunei: the mismatch between employers expectations and employees aspirations", International Journal of Asian Business and Information Management, Vol. 11 No. 2, pp. 88-101.

Musara, M., Mabila, T., Gwaindepi, C. and Netsai, D.L. (2020), "Entrepreneurial activity for economic growth and unemployment reduction in South Africa", International Journal of Entrepreneurship, Vol. 24 No. 2, pp. 1-8, available at: https://searchproquestcom.ezproxy. nottingham.edu.my/scholarly-journals/entrepreneurial-activity-economicgrowth/docview/ $2425832606 /$ se-2?accountid $=135175$.

Nieminen, L. and Hytti, U. (2016), "Commitment to an entrepreneurship training programme for selfemployed entrepreneurs, and learning from participation", Education + Training, Vol. 58, pp. 7-8, doi: 10.1108/ET-02-2016-0036.

Padilla Rodriguez, B.C., Armellini, A. and Rodriguez Nieto, M.C. (2020), "Learner engagement, retention and success: why size matters in massive open online courses (MOOCs)", Open Learning: The Journal of Open, Distance and e-Learning, Vol. 35 No. 1, pp. 46-62.

Pujar, S. and Tadasad, P. (2016), "MOOCs - an opportunity for international collaboration in LIS education", New Library World, Vol. 117 Nos 5/6, pp. 360-373.

Ricart, S., Villar-Navascués, R.A., Gil-Guirado, S., Hernández-Hernández, M., Rico-Amorós, A.M. and Olcina-Cantos, J. (2020), "Could MOOC-takers' behavior discuss the meaning of success-dropout rate? Players, auditors, and spectators in a geographical analysis course about natural risks", Sustainability, Vol. 12 No. 12, pp. 1-18, doi: 10.3390/su12124878.

Saeed, S., Yousafzai, S.Y., Yani-De-Soriano, M. and Muffatto, M. (2015), "The role of perceived university support in the formation of students' entrepreneurial intention”, Journal of Small Business Management, Vol. 53 No. 4, pp. 1127-1145, doi: 10.1111/jsbm.12090. 
Shapiro, H.B., Lee, C.H., Roth, N.E.W., Li, K., Çetinkaya-Rundel, M. and Canelas, D.A. (2017), "Understanding the massive open online course (MOOC) student experience: an examination of attitudes, motivations, and barriers", Computers and Education, Vol. 110, pp. 35-50.

Sithole, B.M. and Lumadi, M.W. (2012), "Pedagogical challenges besetting business studies teachers in secondary schools: a Botswana perspective", Journal of Social Sciences, Vol. 32 No. 1, pp. 71-80, doi: 10.1080/09718923.2012.11893053.

Solórzano-García, M., Navio-Marco, J. and Laguia, A. (2020), "The influence of intrinsic motivation and contextual factors on MOOC students' social entrepreneurial intentions", Interactive Learning Environments, available at: https://doi-org.ezproxy.nottingham.edu.my/10.1080/10494820.2020. 1769680 (accessed 14 April 2021).

Soylev, A. (2017), "MOOCs 2.0: the social era of education", The Turkish Online Journal of Distance Education, Vol. 18 No. 2, pp. 56-67.

Subramaniam, T.T., Suhaimi, N.A., Latif, L.A., Kassim, Z. and Fadzil, M. (2019), "MOOCs readiness: the scenario in Malaysia", International Review of Research in Open and Distance Learning, Vol. 20 No. 3, pp. 80-101.

The World Bank (2020), "Unemployment, total (\% of the total labor force) (modeled ILO estimate) Bangladesh, Indonesia", available at: https://data.worldbank.org/indicator/SL.UEM.TOTL.ZS? locations =BD-ID (accessed 29 September 2020).

Toma, S.G., Grigore, A.M. and Marinescu, P. (2014), "Economic development and entrepreneurship", Procedia Economics and Finance, Vol. 8, pp. 436-443, doi: 10.1016/S2212-5671(14)00111-7.

Uddin, M.M. and Hossain, K.M. (2019), "Quality assessment of master of education (M. Ed) program under blended mode at Bangladesh Open University", 1st International Conference on Education in the Digital Ecosystem (ICEdDE 2019), 19-22 August 2019, Kuching, Malaysia, pp. 250-270, doi: 10.12783/dtssehs/ICEdDE2019/33700.

Vorbach, S., Maria Poandl, E. and Korajman, I. (2019), "Digital entrepreneurship education: the role of MOOCs", International Journal of Engineering Pedagogy, Vol. 9 No. 3, pp. 99-111.

Welsh, D.H. and Dragusin, M. (2013), "The new generation of massive open online course (MOOCS) and entrepreneurship education”, Small Business Institute Journal, Vol. 9 No. 1, pp. 51-65.

Zhou, M. (2016), “Chinese university students' acceptance of MOOCs: a self-determination perspective", Computers and Education, Vol. 92, pp. 194-203.

Zuhairi, A. (2020), "The operational aspects of open and distance learning and its quality assurance system in Universitas Terbuka”, Jurnal Pendidikan Terbuka Dan Jarak Jauh, Vol. 20 No. 2, pp. 74-89, doi: 10.33830/ptjj.v20i2.122.2019.

\section{Corresponding author}

Md. Meraz Ahmed can be contacted at: mnmerazmkt@gmail.com
Attitude towards entrepreneurship development MOOCs 